\title{
Non-monophyly of Bostrychia simpliciuscula (Ceramiales, Rhodophyta): multiple species with very similar morphologies, a revised taxonomy of cryptic species
}

\author{
Giuseppe C. Zuccarello ${ }^{1 *}$, John A. West ${ }^{2}$ and Mitsunobu Kamiya ${ }^{3}$
}

\author{
${ }^{1}$ School of Biological Sciences, Victoria University of Wellington, P.O. Box 600, \\ Wellington, New Zealand \\ ${ }^{2}$ School of Biosciences 2, University of Melbourne, Parkville VIC 3010, Australia \\ ${ }^{3}$ Faculty of Marine Bioscience, Fukui Prefectural University, 1-1 Gakuencho, Obama, Fukui, 917-0003 \\ Japan
}

Corresponding author: joe.zuccarello@vuw.ac.nz. Tel: +64 44636414.

Communicating Editor: Wendy Nelson

This is the author manuscript accepted for publication and has undergone full peer review but has not been through the copyediting, typesetting, pagination and proofreading process, which may lead to differences between this version and the Version of Record. Please cite this article as doi: $10.1111 /$ pre.12207

This article is protected by copyright. All rights reserved. 


\section{SUMMARY}

The discovery of a plethora of cryptic species in many algal groups has led to speculation as to causes of this observation and has affected taxonomy, with reluctance to give names to species that look identical. While this is defensible for monophyletic cryptic species complexes, both our understanding of similar morphologies (crypsis) and nomenclature is challenged when we encounter non-monophyletic 'cryptic' species. Bostrychia simpliciuscula is a wide-ranging species in which multiple cryptic species are known. Our increased sampling shows that this species consists of four lineages that do not form a clade, but lineages are sister to species with different morphologies. Careful morphological examination shows that characters, especially branched monosiphonous laterals and rhizoid morphology in haptera, are able to distinguish these four lineages into two groups, that are still not monophyletic. The similar morphologies in these lineages could be due to convergence, but not developmental constraints or lack of time to diverge morphologically; or possibly maintenance of a generalized body plan. These lineages appear to have specific biogeographic patterns and these will be used to propose a new taxonomy. $B$. simpliciuscula is now confined to the tropics. Another of these lineages matches a previously described species, $B$. tenuissima, that was synonymized with B. simpliciuscula and is from cold temperate Australasia, and is resurrected. Another lineage is found in Japan in which a previous name is also available, B. hamana-tokidae; the last lineage is found in central New South Wales, morphologically it resembles $B$. tenuissima, with which it overlaps in distribution around Sydney, and is named as a new species, B. kingii sp. nov. 
Key words: Australia, Bostrychia kingii sp. nov., convergence, Japan, morphological stasis, Rhodomelaceae

This article is protected by copyright. All rights reserved. 


\section{INTRODUCTION}

The discovery of cryptic species (i.e., distinct genetic/reproductive/ecological entities that are not distinguishable morphologically) is becoming common place in many algal groups. These species can be inferred from a variety of molecular markers including mitochondrial, nuclear and plastid genes. Cryptic species are nearly always found in what was previously thought to be one wide-ranging species, which now appears to be composed of several, to many, distinct evolutionary lineages with narrower ranges. Many of these cryptic species are found to be sister to each other within a diverse clade.

The hypotheses proposed for this high proportion of species that are not morphologically distinguishable, especially in some macroalgae, are many but, include: 1) diversification (speciation) without concomitant morphological change, possibly due to developmental constraints or stabilizing selection (Charlesworth et al. 1982) (morphological stasis); or 2) the low number of morphological characters we can use to distinguish between species (low complexity problem; Verbruggen 2014).

Cryptic species are being reported very frequently in many well sampled algal studies and in all algal groups (e.g., Conklin \& Sherwood 2012; Payo et al. 2013; Skaloud \& Rindi 2013; Niwa et al. 2014; Kogame et al. 2015; Zuccarello et al. 2015; Lyra et al. 2016; Montecinos et al. 2017). These cryptic species are usually inferred by several 'species delimitation' methods (Leliaert et al. 2014), but also by phylogenetic methods indicating strong support for lineages that are morphologically indistinguishable and therefore "putative species" (e.g., Boo et al. 2015). In some cases these cryptic species have been shown to differ in other ways including ecological

This article is protected by copyright. All rights reserved. 
specialization (Skaloud \& Rindi 2013; Muangmai et al. 2016) and reproductive isolation (Zuccarello \& West 2003; Peters et al. 2010).

Cryptic species are often found in wide-ranging species that upon molecular inspection are shown to be composed of multiple species with more limited distributions. Many cryptic species complexes have been found in the tropics (Conklin \& Sherwood 2012; Payo et al. 2013; Vieira et al. 2014), but also temperate species can have multiple cryptic species of more limited distribution (Muangmai et al. 2014; Zuccarello \& Martin 2016). This limited, often non-overlapping, distribution suggests that speciation is due to allopatric processes enhanced by the low dispersal ability of many algae (e.g., Krueger-Hadfield et al. 2015).

In nearly all cases, cryptic species are in a well-supported clade, indicating that while speciation has occurred the 'ancestral' morphology has been maintained. This could be due to stabilizing selection on particular morphologies that may have advantages in certain environments (Davis et al.2014), due to a developmental constraint on the alga in which novel morphologies are not possible, or just a lack of time for morphologies to change.

While cryptic species have been commonly uncovered, taxonomic changes have lagged behind. Sometimes this is due to the intricacies of nomenclatural history. Applying type names to individual lineages can be problematic, without corresponding sequence data from the type specimen (Hughey \& Gabrielson 2012), assuming the type is even available. Also a long history of synonymies makes assigning old names to any of the different lineages difficult and therefore discourages proposing new names (see 
De Clerck et al. 2013). This may not be a problem if the cryptic species complex is monophyletic as all the species are more closely related to each other than any morphogically distinct species, and the taxonomy is therefore clade-based.

Bostrychia is a genus in which significant research has revealed many aspects of its evolution (Zuccarello \& West 2011). Cryptic species are known to occur in several species complexes (B. tenella (J.V. Lamouroux) J. Agardh/B. binderi Harvey, Zuccarello et al.. 2015; B. radicans (Montagne) Montagne/B. moritziana (sonder ex Kützing) J.Agardh, Zuccarello \& West 2003; and B. intricata (Bory) Montagne, Fraser et al. 2013, Muangmai et al. 2014). While some cryptic species have relatively wide distributions, some are more limited in their distribution. For examples, in B. intricata, some cryptic species are localized to certain continents (e.g., South Africa, Australia), while other cryptic species have broader distributions (e.g., New Zealand and Chile; Muangmai et al.. 2014).

Another morphospecies that appears to contain cryptic species is the $B$. simpliciuscula Harvey ex J. Agardh/B. tenuissima R.J. King \& Puttock species complex. The taxonomy of Bostrychia was revised in a monograph by King \& Puttock (1989). They proposed several new species as well as formally synonymized several names. Bostrychia tenuissima was a species proposed (King \& Puttock 1989) as a segregate from B. simpliciuscula Harvey ex J. Agardh. They based their decision mostly on the lack of monosiphonous determinate branch tips in B. tenuissima (type locality: Port Fairy, Victoria, southern Australia), while they are found in B. simpliciuscula (King \& Puttock 1989). The distribution of B. tenuissima was reported as from southern 
Queensland (Noosa Heads) to Tasmania, Australia and New Zealand. While $B$. simpliciuscula has a wider distribution not only in Australia, but also the Pacific Islands, and south-east Asia (King \& Puttock 1989). King and Puttock also synonymized several previous names into $B$. simpliciuscula, including $B$. ando $i$ Okamura found in tropical southern Japan (Ryukyu Island) and B. hamana-tokidae E. Post from Kyushu Island, Japan.

Later research showed that samples of B. simpliciuscula from the southern end of this range, south of Sydney, Australia were a distinct plastid RuBisCo spacer haplotype (designated haplotype H1). These samples only had sorbitol as an osmolyte, while north of Sydney two distinct sequences were found (H2 and H3), which contained both sorbitol and dulcitol as an osmolyte (Zuccarello et al. 1999a). Further research, using other genetic markers, confirmed that these three haplotypes were distinct, and $\mathrm{H} 3$ was found as far north as Singapore (Zuccarello \& West 2006). As these lineages (H1-H3) were not monophyletic and monosiphonous branches did not seem to distinguish the lineages, a taxonomic decision was made to synonymize $B$. tenuissima with $B$. simpliciuscula until further research could resolve the lineages (Zuccarello \& West 2006). These results, plus our further sampling and analyses of the B. simpliciuscula, suggests that the taxonomy of this entity needs refining.

\section{MATERIALS AND METHODS}

This article is protected by copyright. All rights reserved. 
Samples have been collected over many years from many sites around the Pacific Ocean (Suppl. Table S1). Collection, isolation and maintenance of cultures are as presented in West and Zuccarello (1999) and West (2005).

DNA extraction, PCR amplification and sequencing are described in Zuccarello et al. (1999b) for the RuBisCo spacer and Zuccarello and West (2006) for $r b c \mathrm{~L}$ and partial large-subunit ribosomal RNA (LSU). Three datasets were produced using available sequences from Genbank and new sequences: $r b c \mathrm{~L}, \mathrm{LSU}$, and combined $r b c \mathrm{~L}-\mathrm{LSU}$. Phylogenetic trees were constructed with maximum-likelihood (ML) using RAxML 7.2.8 (Stamatakis 2006) under the GTRCAT model with partitioned codons for $r b c \mathrm{~L}$. Support for individual nodes was determined by 1000 bootstrap replicates. Bayesian trees were inferred using MrBayes 3.2 (Ronquist et al. 2012) under the GTR + gamma model for 3 million generations with two independent runs, a sampling frequency of 1000 and a burn-in of 300 trees. The $r b c \mathrm{~L}-r b c \mathrm{~S}$ spacer (RuBisCo spacer) was used to place many samples into one of the four recognized lineages. Networks were created for the RuBisCo spacer data set, where within lineage variation was seen, using TCS 1.21 (Clement et al. 2000) to which the sequences could be joined with 95\% confidence.

Morphological characters were investigated in field specimens. The characters explored were: number of pericentral cells per tier (all specimens had 2 tier cells be axial cell); maximum length of monosiphonous laterals; whether the monosiphonous lateral branched, position of peripherohaptera- adjacent to lateral branches (nodal) or not (intermodal); whether the peripherohaptera are stalked at their bases (a coalescence of rhizoids adjacent to the axis) or had loose rhizoids (sessile), following King and 
Puttock (1989).

\section{RESULTS}

We expanded the distribution of collections to include the central Pacific (e.g., Federated States of Micronesia, Palau) and north Pacific (Japan). In total, 55 samples were sequenced with one or more molecular markers (Table S1). Our combined phylogenetic analyses of samples, all initially identified as $B$. simpliciuscula, indicates that this morphology is polyphyletic with four distinct lineages (presently called H1H4) (Fig. 1). The $r b c L$ (Suppl. Fig. S1) and partial LSU phylogenies (Suppl. Fig. S2) while less supported did not contradict this conclusion. A clade, with high support in the combined analysis, contains two B. simpliciuscula lineages (H1 and H4) plus two other morphologically distinct species (B. tangatensis E. Post and B. scorpioides (Hudson) Montagne). Within this clade there is a supported grouping of $B$. scorpioides and $B$. simpliciuscula $\mathrm{H} 1$; plus in the LSU analysis these two species group with $B$. flagellifera E. Post with strong support; and B. tangatensis with B. simpliciuscula H4. Our RuBisCo spacer analysis, of more samples, shows that samples of $B$. simpliciuscula $\mathrm{H} 1$ have a restricted cold temperate distribution and only one haplotype is found. H1 is found in New Zealand, southern Australia (Tasmania, South Australia) and from Botany Bay, Sydney southward on the east and south coast of Australia. This southerly distribution pattern corresponds to previous research on this lineages distribution (Zuccarello et al. 1999). H4 is found in Japan including the main islands of Honshu, Kyushu and Shikoku. Lineage $\mathrm{H} 3$ is sister to the clade containing B. tangatensis and B. scorpioides

This article is protected by copyright. All rights reserved. 
and lineages $\mathrm{H} 1$ and $\mathrm{H} 4$ with moderate support. $\mathrm{H} 3$ is found wide ranging throughout the tropical Pacific from northern New South Wales, Australia (Brunswick Heads) to Singapore and in the Federated States of Micronesia and Palau (Table S1). This wide ranging lineage also has four RuBisCo spacer haplotypes (Fig. 2), with most samples with haplotype H3a, with distinct haplotypes for samples from Australia and Singapore and two of the samples from Micronesia (Table S1). These three lineages of $B$. simpliciuscula (H1, H3, H4) also form a moderately supported clade with other mostly corticated Bostrychia species (B. binderi, B. tenella, B. montagnei). The phylogenetic position of $B$. simpliciuscula lineage $\mathrm{H} 2$ is very different. It is not closely related to the other three lineages (Fig. 1), but groups with species mostly from the cold temperate southern hemisphere (B. arbuscula W.H. Harvey, B. gracilis (R.J. King \& Puttock) Zuccarello \& J.A. West, B. intricata, B. vaga J.D. Hooker \& Harvey), this group also contains the species $B$. harveyi Montagne and B. calliptera (Montagne) Montagne. Inspection of field material did not find any characters that could separate all four species (Suppl. Table S2). The morphological characters that have been used to separate species within the $B$. simpliciuscula complex have been few, but King and Puttock (1989) suggested that presence of monosiphonous lateral branches and the morphology of peripherohaptera, stalked versus free rhizoids, could separate $B$. simpliciuscula (with monosiphonous laterals and free rhizoids) from B. tenuissima (polysiphonous throughout and stalked rhizoids). Our measurements of field samples (with variable sampling within clades) suggest that two main grouping can be found. Monosiphonous lateral branches do not seem to define particular clades but branching of those 
monosiphonous laterals does seem to fall into two groupings. Lineages $\mathrm{H} 1$ and $\mathrm{H} 2$ with short monosiphonous tips to lateral branches ( $2-7$ cells) and no monosiphonous branching of these laterals, and lineages $\mathrm{H} 3$ and $\mathrm{H} 4$ with longer monosiphonous tips to lateral branches (3-30 cells) and monosiphonous branching of these laterals. Also the morphology of the peripherohaptera appears to be distinct between these two groupings. Lineages $\mathrm{H} 1$ and $\mathrm{H} 2$ have mostly stalked peripherohaptera, while lineages $\mathrm{H} 3$ and $\mathrm{H} 4$ have free rhizoids for their peripherohaptera. Samples of lineages H1 and H2, while not monophyletic, conform closely to the morphology of B. tenuissima. Samples of H3 and H4 are similar to B. simpliciuscula (sensu King \& Puttock 1989). While there is no morphology that unambiguously separates these species, i.e. there is some variation in haptera morphology within species, and no characters seem to even tentatively separate the groups into four species, we propose that the species be defined by their biogeographic distribution. We propose that the following taxonomic changes be made:

\section{New circumscription: Bostrychia simpliciuscula Harvey ex J. Agardh}

1863: 854. Type locality: (Friendly Islands) Tonga.

For samples belonging to lineage H3, which seems to be found throughout, and possibly restricted to, the tropics (Federated States of Micronesia, Guam, Palau, Singapore, central eastern Australia), have peripherohaptera mostly with free rhizoids and branched monosiphonous laterals.

This article is protected by copyright. All rights reserved. 
Resurrected species: Bostrychia tenuissima R.J. King \& Puttock 1989: 18. Type locality: Port Fairy, Victoria, Australia.

Plants with morphology as stated in King and Puttock (1989) but with a more cold temperate distribution. For samples belonging to lineage H1, found in temperate Australia, from Sydney NSW southward, South Australia, Victoria, Tasmania, and New Zealand. This follows the distribution cited by King and Puttock (1989) for the most part, but they proposed a northern distribution to $26^{\circ} \mathrm{S}$, which include the distribution of lineage H2. A small diagnostic amendment to the description, occasionally lateral branch tips are short monosiphonous, 2-7 cells, but this is probably environmentally variable.

Resurrected species: Bostrychia hamana-tokidae E. Post 1941: 208.

Type locality: Kedo River, Makurazaki, “Satsuma Province” Kagoshima Prefecture, Kyushu, Japan.

For samples belonging to lineage $\mathrm{H} 4$ with morphology of $B$. simpliciuscula but found in the main islands of Japan. This species is found in Honshu, Shikoku and Kyushu. An older species name conforming to the morphology of B. simpliciuscula (and B. hamana-tokidae) is found in the Japanese tropical island of Okinawa (Ryukyu Islands), B. andoi Okamura (1907). At present we do not know if this species belongs to lineage H4 or is part of the tropical species H3 (B. simpliciuscula). Samples from Okinawa, which we were unable to amplify, morphologically could be H3 or H4 (Table

This article is protected by copyright. All rights reserved. 
S2). Collection of this 'species' from Okinawa is needed to resolve if this name is appropriate.

New species: Bostrychia kingii Zuccarello, J.A. West \& M. Kamiya sp. nov. (Fig. $3 \mathrm{~A}-\mathrm{F})$.

For samples belonging to lineage $\mathrm{H} 2$ and showing the morphology of $B$. tenuissima.

Diagnosis: Morphology undistinguishable from B. tenuissima. Mostly ecorticate, branching irregular, with a few cortical cells in some older branches. Two tier of pericentral cells per axial cell with 4-5 pericentral cells per tier. Very short monosiphonous tips (2-7 cells) on lateral branches but no monosipohous branching. Peripherohapetera mostly with 'stalked' rhizoids (a coalescence of rhizoids adjacent to the axis).

Type Locality: Forster, New South Wales, Australia (32 $\left.10^{\circ} \mathrm{S} 152^{\circ} 30^{\prime} \mathrm{E}\right)$.

Holotype: MEL 2409237

Isotype: MICH701905, dried JAW3562 culture.

Genbank Accession Numbers: rbcL: AY920827; LSU: AY920877

Distribution: This species has a limited distribution in central NSW, Australia $\left(28^{\circ}-34^{\circ} \mathrm{S}\right)$, but overlaps with B. tenuissima in its southern range (e.g., Wooloware, Botany Bay, NSW) and may also overlap with B. simpliciuscula in its northern range, more sampling in these 'edge' areas is needed.

This article is protected by copyright. All rights reserved. 
Etymology: kingii = in honour of Robert J. King for his pioneering work on the taxonomy of mangrove algae, especially Bostrychia, and appropriately this species appears to be confined to NSW where he spent his scientific career.

\section{Description .}

Plants with prostrate axis and uprights up to $6 \mathrm{~mm}$ (Fig. 3A, B). Two tier cells per axial cell and 4-6 pericentral cells per tier around the main axial cell (Fig. 3C). Plant mostly ecorticate, but occasional cortical cells in older axes. Determinate lateral branches unbranched or with 1-2 order of branching (Fig. 3B). Occasionally laterals with, up to 6 cell monosiphonous tips (Fig. 3D). Peripherohaptera, adjacent or not to lateral branches, rhizoidal cells in coalescence branch (stalked) (Fig. 3E). Tetrasporangia $(50-75 \mu \mathrm{m})$ in unbranched stichidia, tetrahedrally divided (Fig. 3F).

\section{DISCUSSION}

We find a very similar morphology in four non-monophyletic lineages that have all been previously identified as $B$. simpliciuscula. While cryptic, or pseudocryptic, species are reported commonly, most of these cryptic species complexes are monophyletic (Zuccarello \& West 2003; Payo et al. 2013; Muangmai et al. 2014). This monophyly of cryptic species suggests that morphological diversification has not kept pace with genetic differentiation and species most likely retain their ancestral morphology. The reasons for this could be constraints on morphological diversification (developmental constraints), maintenance of morphology due to natural selection or lack of any force,

This article is protected by copyright. All rights reserved. 
e.g., drift, leading to diversification. While these are possible for monophyletic cryptic species, our present results may need other explanations.

Careful examination of our available field collected molecularly identified specimens suggests that two morphologies could be discerned. One of these morphologies correspond to the species described by King and Puttock (1989) as $B$. tenuissima, the other morphologically matches the more wide ranging species $B$. simpliciuscula. While these groups are recognizable they have few diagnostic characters that don't overlap, and still these characters do not define all four species. The only morphological character that appears to be diagnostic is branching in the monosiphonous lateral branches which appears to be confined to B. simpliciuscula and B. hamana-tokidae and not found in B. tenuissima and B. kingii. This character is probably not seen in all specimens. Along with this diagnostic character, there appears to be differences in peripherohaptera morphology with free rhizoids in B. simpliciuscula and B. hamana-tokidae, while the rhizoidal cells are fused into a stalk in the other two species. This character is not consistent within species groups and could be environmentally plastic. There are slightly more tiers of pericentral cells in $B$. tenuissima and B. kingii (4-6) than the other two species (4-5).

While these morphologies help in differentiating some of these species lineages they still do not define four species, nor are they found in monophyletic species groups. For example, branched monosiphonous branches are found in B. simpliciuscula (lineage H3) and B. hamana-tokidae (H4), these two species form a clade with B. tenuissima (lineage H1), plus two morphological distinct species B. scorpioides and B. tangatensis. 
While these two species also have peripherohaptera for attachment, B. scorpioides is heavily corticated, and $B$. tangatensis has $3(-4)$ tiers of cells per axial cell, a character previously used for generic separation (King \& Puttock 1989). B. kingii which is indistinguishable from $B$. simpliciuscula, is found in a larger clade not closely related to these previous species. So what could be causing these similar morphologies in so many clades? While the slight morphological difference between these four species could be attributable to some sort of constraints on morphology if these lineages were monophyletic, that they are sister to species that are morphologically quite distinct, in the context of the genus Bostrychia, indicates that the inability to change morphologically in probable not a reason. The lack of time for morphologies to diverge is also unlikely as they again are sister to species that are quite distinct morphologically. It is possible that convergence could have made these four species so similar. Convergence usually is invoked when phenotypic similarity is found in distantly related taxa and is considered evidence that natural selection has produced these evolutionary changes, usually leading to convergent adaptations (Losos 2011). What the adaptation for the particular morphology of these species is, that would have led to their convergence, is unknown. A comparative phylogenetic approach could be useful, but in this case it is difficult to evoke a selective pattern. B. simpliciuscula and B. kingii are both associated with mangrove habitats, especially on the bark and pneumatophores of mangrove trees. It is possible that these environments have driven this morphological convergence. Yet, these two species are very similar to $B$. hamana-tokidae and $B$. tenuissima, respectively, that are mostly not associated with mangroves but are found in 
rivers (in central Japan) or salt marshes (in colder areas- e.g., New Zealand) were different selection forces may be operating.

It is also possible that what we have is a group of species that have been misidentified (lumped) because they have not evolved diagnostic characters, maybe by retaining a general body plan. While a combination of characters in Bostrychia has been used to define species, these four studied species seem to have a basic undifferentiated plan. For example, B. tenuissima is sister to B. scorpioides, which has evolved dense cortication and circinate apices. B. hamana-tokidae is sister to B. tangatensis but the latter has three tiers of pericentrals per axial cell. B. kingii is sister to a group of species found in the cold temperate southern hemisphere that have both cortication and three or more tiers of pericentral cells per axial cell, while still retaining peripherohaptera. It is possible that what we have here is a lack of morphological evolution in a genus with few characters in the first place, it is possible that this 'non-descript' morphology is ancestral or a generalized body plan without any apparent change over time.

We have proposed to name these cryptic species, even though they are not morphologically distinguishable. While maintaining a single descriptor name for a clade composed of many cryptic is defensible (i.e., all cryptic species are more closely related to each other than to any other morphologically distinct species; e.g., Muangmai et al. 2014; Boo et al. 2015), in this case we do not believe that maintaining a polyphyletic species aids understanding of diversity. We believe that in order to move taxonomy forward the names proposed should be applied to these taxa. At present the biogeographic distribution of these species is mostly quite distinct and this should be 
used to 'identify' the species in a particular location. The changes in distribution that may occur with further sampling should not hinder these taxonomic changes. The taxonomic changes also are minimally disruptive. Many references to B. simpliciuscula are from tropical regions (Silva et al. 1996; Atmadja \& Prud'homme van Reine 2012), so these records will not need updating. Cold temperate regions have the species $B$. tenuissima which has been used since 1989 (Adams 1994; Womersley 2003). Records from New South Wales, Australia are problematic, if the species is found in the south central region it could be B. tenuissima or B. kingii if it lacks branched monosiphonous laterals and has stalked peripherohaptera. In central northern New South Wales it could be $B$. kingii if it has the previous morphology or B. simpliciuscula if it has branched monosiphonous laterals and free rhizoids. In the cool temperate northern hemisphere the issue of distribution of $B$. hamana-tokidae versus the extent of $B$. simpliciuscula needs to be investigated. For example, which species is found in China (Liu 2008) or Korea (Nam \& Kang 2012)?

It is possible that continued study of these morphologically similar species will uncover morphological differences, but it is clear that these characters will not be readily accessible to most biologist, and the real possibility that no characters will be found must be accepted in organisms with low morphological diversity and available characters that environmentally plastic (Verbruggen 2014).

We believe our proposed changes update the taxonomy of Bostrychia to more closely reflect the evolution and biodiversity of the group. Interestingly there appears to

This article is protected by copyright. All rights reserved. 
be one other polyphyletic species in the genus, samples identified as B. calliptera (Zuccarello \& West 2006), resolving this morphospecies will require further study.

\section{ACKNOWLEDGMENTS}

We thank the Japanese Society for the promotion of Science (JSPS) for a fellowship to GCZ. We also thank our many collectors that have sent samples over the years.

\section{REFERENCES}

Adams, N. M. 1994. Seaweeds of New Zealand. Canterbury University Press.

Agardh, J. G. 1863. Species, genera et ordines floridearum, seu descriptiones succinctae specierum, generum et ordinum. Vol. 2. Gleerup, Lund. pp. 701-1291.

Atmadja, W.S. and Prud'homme van Reine, W.F. 2012. Checklist of the seaweed species biodiversity of Indonesia with their distribution and classification: Rhodophyceae. Coral Reef Rehabilitation and Management Programme. Indonesian Institute of Sciences (LIPI). Jakarta.

Boo, G.-H., Nelson, W.A., Preuss, M., Kim, J.Y. and Boo, S.M. 2015. Genetic segregation and differentiation of a common subtidal alga Pterocladia lucida (Gelidiales, Rhodophyta) between Australia and New Zealand. J Appl Phycol. 28: 2027-34.

Charlesworth, B., Lande, R. and Slatkin, M. 1982. A neo-Darwinian commentary on macroevolution. Evolution. 36: 474-98.

This article is protected by copyright. All rights reserved. 
Clement, M., Posada, D. and Crandall, K. A. 2000. TCS: a computer program to estimate gene genealogies. Mol. Ecol. 9: 1657-9.

Conklin, K.Y. and Sherwood, A.R. 2012. Molecular and morphological variation of the red alga Spyridia filamentosa (Ceramiales, Rhodophyta) in the Hawaiian Archipelago. Phycologia 51: 347-57.

Davis, C.C., Schaefer, H., Xi, Z., Baum, D.A., Donoghue, M.J. and Harmon, L.J. 2014. Long-term morphological stasis maintained by a plant-pollinator mutualism. Proc. Natl. Acad. Sci. U.S.A. 111: 5914-9.

De Clerck, O., Guiry, M.D., Leliaert, F., Samyn, Y. and Verbruggen, H. 2013. Algal taxonomy: a road to nowhere? J. Phycol. 49: 215-25.

Fraser, C.I., Zuccarello, G.C., Spencer, H.G., Salvatore, L.C., Garcia, G.R. and Waters, J.M. 2013. Genetic Affinities between Trans-Oceanic Populations of Non-Buoyant Macroalgae in the High Latitudes of the Southern Hemisphere. PLOS ONE. 8: e69138.

Hughey, J.R. and Gabrielson, P.W. 2012. Comment on "Acquiring DNA sequence data from dried archival red algae (Florideophyceae) for the purpose of applying available names to contemporary genetic species: a critical assessment" Botany $\mathbf{9 0}$ : 191-203.

King, R.J. and Puttock, C.F. 1989. Morphology and taxonomy of Bostrychia. Aust. Syst. Bot. 1: 1-73.

Kogame, K., Ishikawa, S., Yamauchi, K., Uwai, S., Kurihara, A. and Masuda, M. 2015. Delimitation of cryptic species of the Scytosiphon lomentaria complex

This article is protected by copyright. All rights reserved. 
(Scytosiphonaceae, Phaeophyceae) in Japan, based on mitochondrial and nuclear molecular markers. Phycol. Res. 63: 167-77.

Krueger-Hadfield, S.A., Roze, D., Correa, J.A., Destombe, C. and Valero, M. 2015. O father where art thou? Paternity analyses in a natural population of the haploiddiploid seaweed Chondrus crispus. Heredity 114: 185-94.

Leliaert, F., Verbruggen, H., Vanormelingen, P., Steen, F., López-Bautista, J.M., Zuccarello, G.C. and De Clerck, O. 2014. DNA-based species delimitation in algae. Eur. J. Phycol. 49: 179-96.

Liu, J. Y. (Ed.) 2008. Checklist of Biota of Chinese Seas. Beijing: Science Press, Academia Sinica.

Losos, J.B. 2011. Convergence, adaptation, and constraints. Evolution 65: 1827-40.

Lyra, G. de M., Gurgel, C.F.D., Costa, E.D.S., et al.. 2016. Delimitating cryptic species in the Gracilaria domingensis complex (Gracilariaceae, Rhodophyta) using molecular and morphological data. J. Phycol. 52: 997-1017.

Montecinos, A.E., Couceiro, L., Peters, A.F., Desrut, A., Valero, M. and Guillemin, M.L. 2017. Species delimitation and phylogeographic analyses in the Ectocarpus subgroup siliculosi (Ectocarpales, Phaeophyceae). J. Phycol. 53: 17-31.

Muangmai, N., Ammon, von, U. and Zuccarello, G.C. 2016. Cryptic species in sympatry: nonrandom small-scale distribution patterns in Bostrychia intricata (Ceramiales, Rhodophyta). Phycologia 55: 424-30.

This article is protected by copyright. All rights reserved. 
Muangmai, N., West, J.A. and Zuccarello, G.C. 2014. Evolution of four southern hemisphere Bostrychia (Rhodomelaceae, Rhodophyta) species: phylogeny, species delimitation and divergence times. Phycologia 53: 593-601.

Nam, K.W. and Kang, P.J. 2012. Algal flora of Korea. Volume 4, Number 4. Rhodophyta: Ceramiales: Rhodomelaceae: 18 genera including Herposiphonia. Incheon: National Institute of Biological Resources.

Niwa, K., Kikuchi, N., Hwang, M.S., Choi, H.-G. and Aruga, Y. 2013. Cryptic species in the Pyropia yezoensis complex (Bangiales, Rhodophyta): Sympatric occurrence of two cryptic species even on same rocks. Phycol. Res. 62: 36-43.

Okamura, K. 1907. Icones of Japanese Algae. Vol. 1. Kazamashobo, Tokyo.

Payo, D.A., Leliaert, F., Verbruggen, H., D'hondt, S., Calumpong, H.P. and De Clerck, O. 2013. Extensive cryptic species diversity and fine-scale endemism in the marine red alga Portieria in the Philippines. Proc. R. Soc. Lond. B Bio. 280: 20122660.

Peters, A.F., Van Wijk, S.J., Cho, G.Y., et al. 2010. Reinstatement of Ectocarpus crouaniorum Thuret in Le Jolis as a third common species of Ectocarpus (Ectocarpales, Phaeophyceae) in Western Europe, and its phenology at Roscoff, Brittany. Phycol. Res. 58: 157-70.

Post, E. 1941. Bostrychia hamana-tokidai spec. nov., eine neue süd-japanische Bostrychia. Beihefte zum Botanischen Centralblatt Abt. B 61: 208-10.

Ronquist, F., Teslenko, M., van der Mark, P., et al. 2012. MrBayes 3.2: Efficient Bayesian phylogenetic inference and model choice across a large model space. Syst. Biol. 61: 539-42.

This article is protected by copyright. All rights reserved. 
Silva P.C., Basson P.W. and Moe R.L. 1996. Catalogue of the Benthic Marine Algae of the Indian Ocean. University of California Publications in Botany. 79: 1-1259.

Skaloud, P. \& Rindi, F. 2013. Ecological differentiation of cryptic species within an asexual protist morphospecies: A case study of filamentous green alga Klebsormidium (Streptophyta). J. Eukaryot. Microbiol. 60: 350-62.

Stamatakis, A. 2006. RAxML-VI-HPC: maximum likelihood-based phylogenetic analyses with thousands of taxa and mixed models. Bioinformatics 22: 2688-90.

Verbruggen, H. 2014. Morphological complexity, plasticity, and species diagnosability in the application of old species names in DNA-based taxonomies. J. Phycol. 50: $26-31$.

Vieira, C., D'hondt, S., De Clerck, O. and Payri, C.E. 2014. Toward an inordinate fondness for stars, beetles and Lobophora? Species diversity of the genus Lobophora (Dictyotales, Phaeophyceae) in New Caledonia. J. Phycol. 50: 1101-19.

West, J. A. 2005. Long term macroalgal culture maintenance. In Andersen, R. (Ed.) Algal Culturing Techniques. Academic Press, New York, pp. 157-63.

West, J. A. and Zuccarello, G. C. 1999b. Biogeography of sexual and asexual populations in Bostrychia moritiziana (Rhodomelacaeae, Rhodophyta). Phycol. Res. 47: 115-23.

Womersley, H.B.S. 2003. The marine benthic flora of southern Australia. Part IIID: Ceramiales-Delesseriaceae, Sarcomeniaceae, Rhodomelaceae. Australian Biological Resources Study. 533 p.

This article is protected by copyright. All rights reserved. 
Zuccarello, G.C., West, J., Karsten, U. and King, R. 1999a. Molecular relationships within Bostrychia tenuissima (Rhodomelaceae, Rhodophyta). Phycol. Res. 47: 815.

Zuccarello, G.C., West, J.A., Kamiya, M. \& King, R.J. 1999b. A rapid method to score plastid haplotypes in red seaweeds and its use in determining parental inheritance of plastids in the red alga Bostrychia (Ceramiales). Hydrobiologia 401: 207-14.

Zuccarello, G. C. and West, J. A. 2003. Multiple cryptic species: molecular diversity and reproductive isolation in the Bostrychia radicans/B. moritziana complex (Rhodomelaceae, Rhodophyta) with focus on North American isolates. J. Phycol. 39: $948-59$.

Zuccarello, G. and West, J. 2011. Insights into evolution and speciation in the red alga Bostrychia: 15 years of research. Algae 26: 21-32.

Zuccarello, G.C. and Martin, P. 2016. Phylogeography of the Lessonia variegata species complex (Phaeophyceae, Laminariales) in New Zealand. Algae 31: 91-103. Zuccarello, G.C. and West, J.A. 2006. Molecular phylogeny of the subfamily Bostrychioideae (Ceramiales, Rhodophyta): subsuming Stictosiphonia and highlighting polyphyly in species of Bostrychia. Phycologia 45: 24-36.

Zuccarello, G.C., Muangmai, N., Preuss, M., Sanchez, L.B. Loiseaux de Goër, S. and West, J.A. 2015. The Bostrychia tenella species complex: morphospecies and genetic cryptic species with resurrection of B. binderi. Phycologia 54: 261-70.

\section{SUPPORTING INFORMATION}

This article is protected by copyright. All rights reserved. 
Additional Supporting Information may be found in the online version of this article at the publisher's web-site:

Fig. S1. A phylogeny of $r b c \mathrm{~L}$ data of species of Bostrychia.

Fig. S2. A phylogeny of partial LSU data of species of Bostrychia.

Table S1. Samples used in study.

Table S2. Morphological characters from field collected material.

This article is protected by copyright. All rights reserved. 


\section{Figure Legends}

Fig. 1. A majority-rule consensus tree generated from the MrBayes analysis of combined $r b c \mathrm{~L}$ and partial LSU of species of Bostrychia. Values on branches $=$ Bayesian posterior probabilities (PP) followed by ML bootstrap percentages $(\mathrm{BP}){ }^{*}{ }^{*}=$ full support of branch (1.0 PP, 100\% BP). Outgroup the cladohaptera containing species Bostrychia radicans. 3-letter country codes used. H1-H3= refer to " $B$. simpliciuscula" linages from Zuccarello et al. (1999a) and Zuccarello and West (2006). H4= Japanese lineage of " $B$. simpliciuscula".

Fig 2. Statistical parsimony network inferred from RuBisCo data of samples of $B$. simpliciuscula (lineage H3). Lines indicate one mutational step; cross lines indicate inferred missing or intermediate haplotypes.

Fig. 3. Morphology of Bostrychia kingii sp. nov. holotype specimen. A) morphology of voucher specimen. B) close up of lateral branching, 0-1 orders of branching, with tetrasporangial stichidia. C) higher magnification of vegetative axis. two tiers cells per axial, lack of cortication and 6 tiers of pericentral cells around the axial cell. D) short monosiphonous tips (arrows) to determinate and indeterminate branches ( $2-4$ cells long). Arrows $=$ monosiphonous tips. E) peripherohapteron (arrow) with coalesced rhizoids (stalked), not associated with a lateral branch. F) Tetrasporangial stichidium showing tetrasporangia (arrows).

This article is protected by copyright. All rights reserved. 


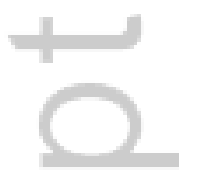

This article is protected by copyright. All rights reserved. 


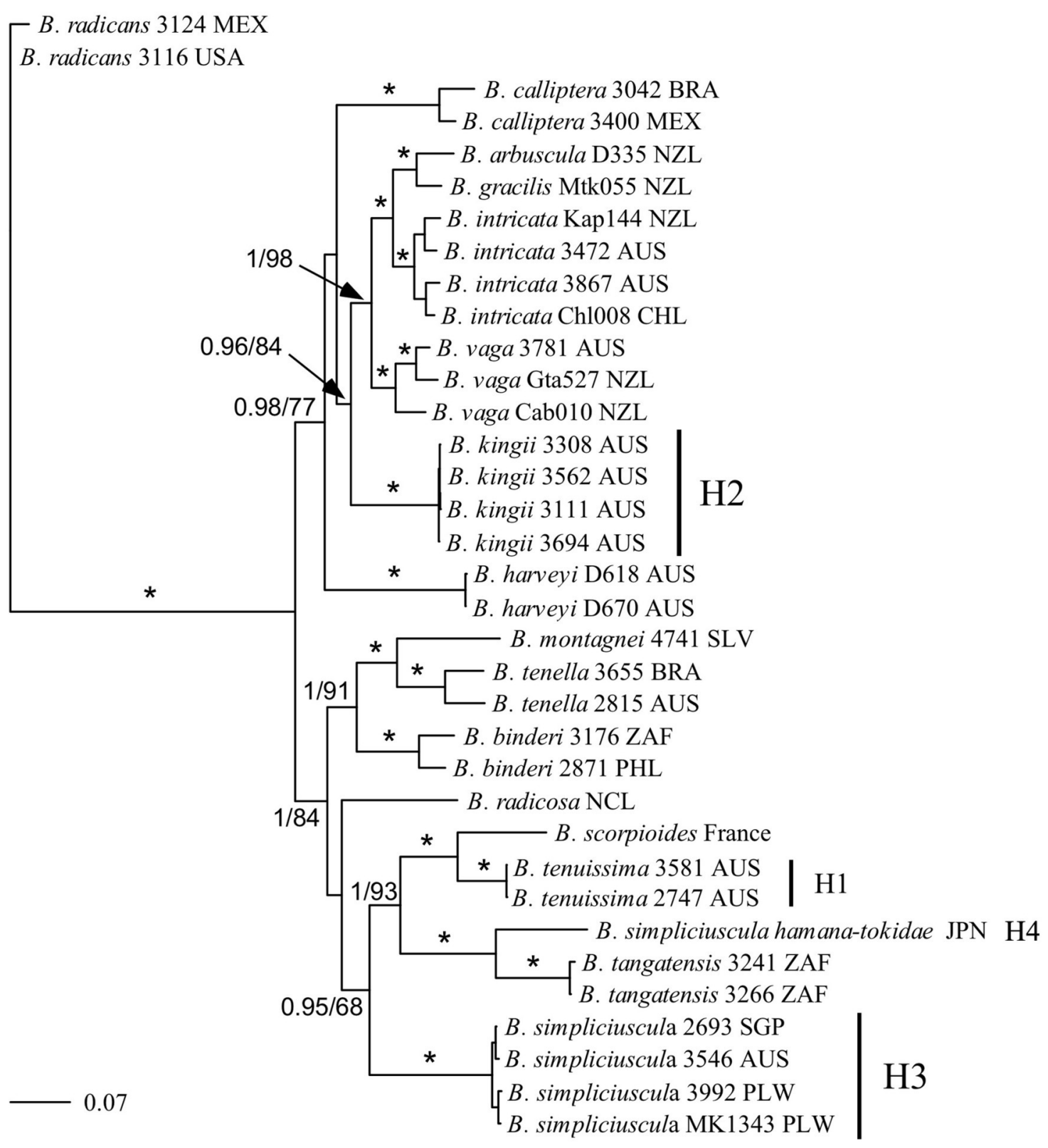

Fig1.revised.jpg 
$\mathrm{a}=$ remainder

$\mathrm{b}=3546$ AUS

$\mathrm{c}=2963$ SGP

$\mathrm{d}=4594$ FSM, 4600 FSM

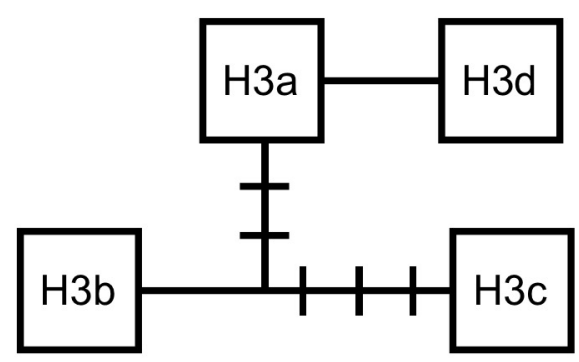

Fig2.jpg

This article is protected by copyright. All rights reserved. 


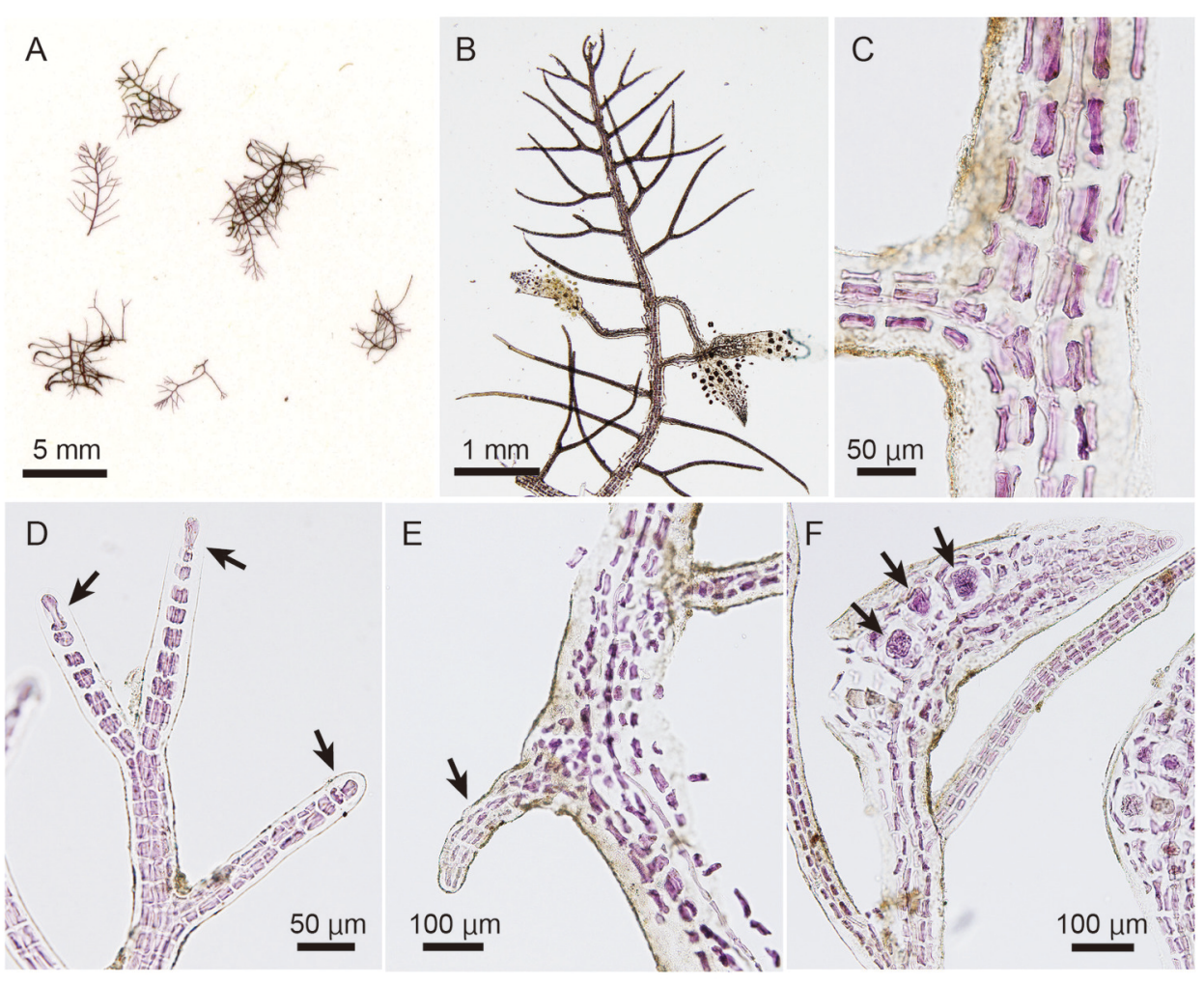

Fig.3.jpg

This article is protected by copyright. All rights reserved. 


\section{University Library}

\section{- M I I N E R VA \\ A gateway to Melbourne's research publications}

Minerva Access is the Institutional Repository of The University of Melbourne

Author/s:

Zuccarello, GC;West, JA;Kamiya, M

Title:

Non-monophyly of Bostrychia simpliciuscula (Ceramiales, Rhodophyta): Multiple species with very similar morphologies, a revised taxonomy of cryptic species

Date:

2018-04-01

Citation:

Zuccarello, G. C., West, J. A. \& Kamiya, M. (2018). Non-monophyly of Bostrychia simpliciuscula (Ceramiales, Rhodophyta): Multiple species with very similar morphologies, a revised taxonomy of cryptic species. PHYCOLOGICAL RESEARCH, 66 (2), pp.100-107. https://doi.org/10.1111/pre.12207.

Persistent Link:

http://hdl.handle.net/11343/294079 